\title{
EDUKASI STRATEGI PENGELOLAAN MANAJEMEN KEUANGAN DIMASA PANDEMI COVID-19 UNTUK MENINGKATKAN KUALITAS PEREKONOMIAN MASYARAKAT
}

\author{
Erfan Efendi*, Devrynda Bela Anggrayny, Lisdiana, Zakiyatun Nufus, Sabilla Tian \\ Safitri, Anisa Putri, Ike Anita, Nabila Soviatul Fitria, Mileinia Sukoco Putri, Jihan \\ Rambu Salsabila \\ Fakultas Ekonomi dan Bisnis, Universitas Islam Malang \\ *korespondensi email: erfanefendi@unisma.ac.id
}

\begin{abstract}
ABSTRAK
Pelaksanakan kegiatan edukasi strategi pengelolaan manajemen keuangan dimasa pandemi Covid-19 yang bertujuan membantu masyarakat dalam peningkatan kualitas perekonomian di Desa Selorejo, Kecamatan Dau, Kabupaten Malang. Memberikan pengetahuan dan pemahaman kepada masyarakat bagaimana menentukan dan memutuskan langkah yang tepatyang dapat diambil untuk pengelolaan keuangan agar tetap sehat guna bertahan hidup khususnya pada situasi pandemi saat ini diketahui perekonomian masyarakat menurun saat pandemi covid-19. Pengaruh permasalahan ini seperti banyaknya usaha yang harus gulung tikar, pemotongan gaji karyawan dan PHK (Pemutusan Hubungan Kerja). Metode kegiatan ini menggunakan metode survei agar mengetahui kebiasaan dan problema masalah pengelolaan keuangan pada Desa Selorejo dengan memaparkan materi secara langsung dan pembahasan tentang perencanaan keuangan di Masa Pandemi Covid-19 untuk peningkatan kualitas ekonomi masyarakat Desa Selorejo. Hasil dari kegiatan tersebut ialah masyarakat Desa Selorejo menjadi paham dan mengerti cara mengelola keuangan secara bijak dengan mengelompokkan kebutuhan dan keinginan. Dari peserta yang mengikuti kegiatan ini, ada $60 \%$ yang telah memahami dan mempraktekkan dalam mengelola keuangan pribadinya. Pengelompokan kebutuhan dan keinginan yang dimaksud adalah mengutamakan atau mendahulukan kebutuhan dari pada keinginan semata.
\end{abstract}

Kata Kunci: strategi pengelolaan keuangan; peningkatan kualitas perekonomian

\section{PENDAHULUAN}

Corona virus merupakan sekelompok virus yang dapat menular dan munculnya sebuah penyakit yang disebut Covid-19 yang sedang kita rasakan saat ini. Covid-19 ini menyerang infeksi saluran pernapasan gejalanya dari batuk, pilek hingga sesak nafas (World Health Organization, 2019). Siapapun dapat terinfeksi virus ini baik bayi maupun orang tua dengan keadaan seperti ini masyarakat harus mentaati kepatuhan terhadap protokol kesehatan seperti 5M (Efendi et al., 2021). Jika terpapar penyakit Covid-19 harus melakukuan isolasi mandiri di rumah dan tidak melakukan kepergian apabila tidak terlalu penting (Novena, 2021).

Virus corona ini sangat berdampak terhadap perekonomian. Sehingga menyebabkan lumpuhnya perekonomian masyarakat dengan menurunnya minat dan investasi masyarakat, dalam berumah tangga atau dalam pemerintahan (Hadiwardoyo, 2020). Pada 
masa Covid-19 ini, untuk mewujudkan kesadaran masyarakat agar mengurangi aktivitas di luar rumah pandemi atas tuntutan bahkan mempengaruhi perekonomian pedagang. Pertumbuhan perekonomian sangat penting di dalam kehidupan masyarakat. Dalam kehidupan manusia sangat bergantung dengan kebutuhan ekonomi. Para UMKM sangat mengalami kerugian karena adanya Virus ini (Hanoatubun, 2020). Dampak yang paling dirasakan masyarakat desa selorejo adalah penurunan pendapatan akibat pandemi.

Merencanakan keuangan itu sangat penting dilakukan oleh semua golongan dan sebelum mengunakan uang lebih baik merencanakan atau memikirkan terlebih dahulu secara mateng agar tidak ada kekurangan (Rizal et al., 2019). Dalam mengelolah keuangan sehari-hari sangatlah penting. Terutama bagi mahasiswa Jurusan Ekonomi harus mampu mengelolah keuangan dengan baik agar terpenuhi kebutuhannya. Menurut Wulandari \& Hakim (2015) mahasiswa dituntut harus mempunyai kecerdasan membaca, menganalisa, mengelolah serta mengkomunikasikan tentang mengelolah keuangan dengan baik.

Dari uraian diatas kami mahasiswa KSM Universitas Islam Malang, melaksanakan Edukasi Strategi Pengelolaan Manajemen Keuangan Di Masa Pandemi Covid-19 Kepada Masyarakat Desa Selorejo agar dapat mengelola keuangan dengan baik. Karena adanya pandemi ini membuat gaya hidup maupun pekerjaan seseorang menjadi berbeda dari biasanya dan kebanyakan dari sebagian orang harus mengelola manajemen keuangan agar biasa bertahan di masa pandemi virus ini. Dengan itu, kegiatan ini diharapkan mampu untuk menyelesaikan permasalahan yang sedang terjadi di lingkunngan masyarakat.

\section{METODE}

Metode dalam kegiatan ini adalah metode survei. Menurut Nazir (2003) metode survei adalah suatu observasi untuk mendapatkan kebenaran fakta dari gejala yang ada dan mengulik keterangan secara otentik, Metode survei mengurai serta mendalami masalahmasalah selain itu juga untuk mendapatkan validitas terhadap keadaan dan praktek-praktek yang sedang berlangsung. Menggunakan metode survei untuk mengetahui kebiasaan dan problema masalah pengelolaan keuangan pada Desa Selorejo. Pihak yang terlibat adalah masyarakat Desa Selorejo, Kecamatan Dau, Kabupaten Malang sebanyak 10 orang.

Bentuk kegiatan yang dilakukan antara lain melakukan penyuluhan, pemaparan materi, dan evaluasi. Bedasarkan kegiatan tersebut terdapat rincian sebagai berikut yaitu tahap pertama melakukan penyuluhan, penyuluhan ini dilakukan untuk mengetahui sejauh mana masyarakat Desa Selorejo dalam memahami pengelolaan keuangan. Tahap kedua yaitu pemaparan materi mengenai bagaimana menerapkan strategi yang tepat untuk perencanaan keuangan yang baik. Strategi yang kami paparkan antara lain: Menyisihkan uang pribadi dengan uang usaha; Membuat daftar pengeluaran dengan sebaik mungkin; Mencatat atau membukukan semua transaksi keuangan yang ada; Memantau dan mengontrol arus kas serta membuat dana cadangan. Selanjutnya evaluasi dilakukan untuk memastikan bahwa masyarakat benar-benar menerapkan strategi pengelolaan manajemen keuangan dengan bijak.

\section{HASIL DAN PEMBAHASAN}

Kegiatan edukasi strategi pengelolaan manajemen keuangan di masa pandemi covid ini dilaksanakan di Desa Selorejo, Malang. Dengan diikuti oleh beberapa warga Desa Selorejo yang dilaksanakan pada tanggal 14 Agustus 2021. Tujuan dari kegiatan ini adalah untuk memberikan bekal bagi masyarakat desa Selorejo agar bisa mengelola keuangan lebih baik. Secara umum masyarakat sangat antusias dalam mengikuti kegiatan ini, terlihat dari respon dan semangat yang mereka tunjukkan saat kegiatan berlangsung. Dari jumlah peserta yang hadir, ada $80 \%$ peserta yang sangat antusias. Melalui progam KSM ini, diharapkan 
masyarakat Desa Selorejo dapat menjadikannya sebagai acuan dalam mengelolah keuangan dan mampu diterapkan di kehidupan sehari-hari.

Kegiatan KSM ini diawali dengan pemaparan materi. Narasumber untuk kegiatan kali ini adalah anggota KSM sendiri. Dengan penyampaian materi ini, masyarakat diberi pemahaman bahwa mengelolaan keuangan dengan baik itu sangat penting agar tidak mengalami kondisi keuangan yang buruk dimasa mendatang. Masyarakat diajarkan untuk mengelola keuangan secara bijak, dengan mengelompokkan kebutuhan dan keinginan. Kemudian pengelompokkan tersebut dijadikan acuan prioritas dimana kelompok kebutuhan harus didahulukan daripada keinginan. Kebutuhan merupakan segala sesuatu yang dibutuhkan berupa barang atau jasa yang harus dipenuhi demi bertahan hidup, seperti makan minum, pakaian, tempat tinggal, keamanan, kenyamanan dan lain-lain. Sedangkan keinginan merupakan sesuatu yang tidak harus dipenuhi karena sifatnya tidak mengikat. Contohnya seperti perhiasan, mobil, tas, laptop, dan lain- lain.

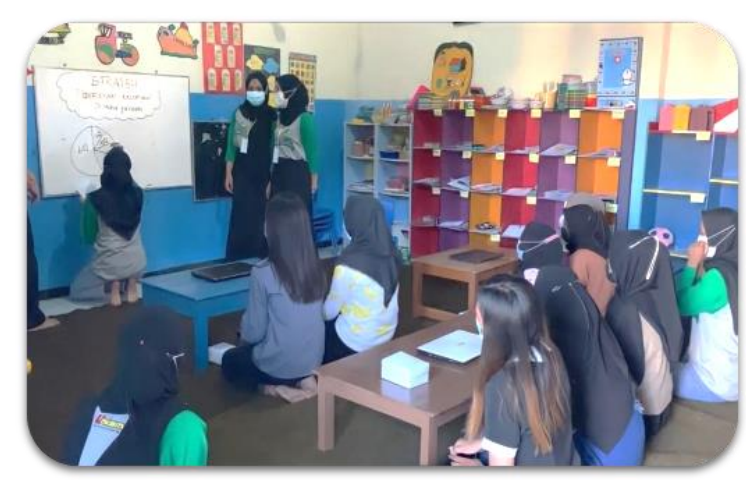

Gambar 1. Pemaparan materi dari mahasiswa KSM-Tematik Unisma

\section{Strategi Mengelola Keuangan}

Kita harus cermat melakukan perencanaan keuangan apalagi dimasa pandemi sekarang ini, agar dapat mencukupi kebutuhan hidup. Ada 4 strategi yang bisa dilakukan dalam membuat perencanaan keuangan. Berikut beberapa strategi mengelola keuangan yang bisa dilakukan dimasa pandemi COVID-19.

\section{Evaluasi Anggaran}

Adanya wabah Covid-19 sangat berpengaruh terhadap pendapatan setiap orang, keadaan ini membuat seluruh orang mencari cara yang tepat untuk mengelola keuangan agar dapat bertahan ditengah pandemi. Untuk itu kita perlu melakukan perencanaan keuangan agar keuangan kita selalu dalam keadaan sehat. Alokasi ideal untuk penghasilan bulanan rata-rata pendapatan masyarakat desa Selorejo 1.500.000.

Pengeluaran:

- $\quad$ Biaya Hidup 60\% $=900.000$

- $\quad$ Tabungan \& Investasi $15 \%=225.000$

- Dana Darurat $10 \%=150.000$

- Gaya Hidup $10 \%=150.000$

- $\quad$ Sosial $5 \%=75.000$

\section{Menyiapkan Dana Darurat}

Untuk saat ini, lebih baik mencari lebih banyak pendapatan. Bahkan dimasa pandemi ini, ada banyak peluang bisnis yang bisa dicari atau dilakukan, seperti bekerja paruh waktu atau memulai bisnis online. Mengumpulkan dana darurat memang penuh tantangan, apalagi dimasa pandemi seperti sekarang ini. Oleh karena itu lakukanlah secara perlahan, sedikit demi sedikit, dan konsisten. 


\section{Investasi}

Jika dana yang perlu di investasikan sudah tersedia. Kita dapat mencoba berinvestasi melalui emas. Investasi logam mulia atau emas sangat aman dan mudah dilakukan oleh siapa saja. Investasi ini dapat membuahkan hasil yang sangat menguntungkan setidaknya dengan jangka waktu minimal lima atau sepuluh tahun. Agar lebih mudah, kita dapat berinvestasi secara online di berbagai aplikasi terpercaya seperti pegadaian digital, tokopedia emas, indogold, dll.

\section{Menabung}

Selain berinvestasi, menabung juga sangat dibutuhkan dalam menjaga kestabilan keuangan. Dengan menabung secara tidak langsung kita telah menyiapkan dana cadangan untuk masa depan. Kita bisa mulai menabung dengan nominal kecil, setelah terbiasa kita bisa menaikkan nominalnya, dan jika sudah terkumpul bisa dipindahkan ke bank karena bank adalah salah satu tempat paling aman untuk menyimpan uang.

Materi yang diberikan adalah mengenai cara mengelola keuangan dan pentingnya diterapkan dalam kehidupan sehari-hari. Pemaparan materi disampaikan dengan fokus materi kepada pengelolaan terhadap keuangan pribadi dan pengalokasikan gaji perbulan. Mengalokasikan gaji perbulan untuk biaya hidup, tabungan dan investasi, dana darurat, gaya hidup, dan sosial. Setelah memahami bagaimana cara mengalokasikan penghasilan yang baik dan benar, mereka tersadar akan pentingnya melakukan pengelolaan terhadap penghasilan mereka.

\section{KESIMPULAN}

Dari paparan yang telah disampaikan terkait pelaksanaan kegiatan PKM Mahasiswa Prodi Akuntansi Universitas Islam Malang, yang bertempat di Desa Selorejo, Kecamatan Dau, Kabupaten Malang, telah mendorong masyarakat agar dapat menyisihkan penghasilan mereka untuk menghemat uang dan menyisihkan uangnya untuk di tabung, investasi, dana darurat, dan sedekah. Serta mendorong Masyarakat Desa Selorejo untuk semangat dalam mencari penghasilan tambahan yang cocok saat pandemi disaat Pandemi seperti saat ini. Alangkah baiknya bijak dalam mengatur keuangan, belanjalah secukupnya sesuai dengan kebutuhan, dan berusaha menghindari pengeluaran yang tidak perlu selain itu harusnya masyarakat saat ini mengelola keuangan secara bijak, dengan mengelompokkan kebutuhan dan keinginan.

\section{DAFTAR RUJUKAN}

Efendi, E., Tsauri, M. S., Putri, A. M. L., Damayanti, L., Kiptiyah, K., Febriana, A., Nurhalisa, S., Kurniawan, H., Safi'in, M., Hutama, D. A., \& Hariyanto, E. (2021). Peningkatan Awareness Masyarakat terhadap Pentingnya Penerapan Protokol Kesehatan 5M sebagai Mitigasi Penyebaran Covid-19. Jurnal Pembelajaran Pemberdayaan Masyarakat (JP2M), 2(4), 348-354. https://doi.org/10.33474/jp2m.v2i4.13461

Hadiwardoyo, W. (2020). Kerugian Ekonomi Nasional Akibat Pandemi Covid-19. Baskara Journal of Business and Enterpreneurship, 2(2), 83-92. https://doi.org/10.24853/baskara.2.2.83-92

Hanoatubun, S. (2020). Dampak Covid-19 terhadap Perekonomian Indonesia. EduPsyCouns: Journal of Education, Psychology and Counseling, 2(1), 146-153. https://ummaspul.ejournal.id/Edupsycouns/article/view/423

Nazir, M. (2003). Metode Penelitian. Ghalia Indonesia.

Novena, M. (2021). Mendampingi Isolasi Mandiri Anak Positif Covid-19, Apa yang Perlu Diperhatikan? Kompas.Com. https://www.kompas.com/sains/read/2021/07/14/100100723/mendampingi- 
isolasi-mandiri-anak-positif-covid-19-apa-yang-perlu?page=all

Rizal, M., Mustapita, A. F., \& Kartika Sari, A. F. (2019). Pelatihan Untuk Pengajuan Pembiayaan Mudharabah Perbankan Syariah Sebagai Peningkatan Kinerja UMKM. Jurnal Inovasi Hasil Pengabdian Masyarakat (JIPEMAS), 3(1), 15-22. https://doi.org/10.33474/jipemas.v3i1.2569

World Health Organization (WHO). (2019). To Grow Up Healthy, Children Need To Sit Less and Play More. World Health Organization (WHO) News. https://www.who.int/news/item/24-04-2019-to-grow-up-healthy-children-need-tosit-less-and-play-more

Wulandari, \& Hakim, L. (2015). Pengaruh Love of Money, Pendidikan Keuangan di Keluarga, Hasil Belajar Manajemen Keuangan, dan Teman Sebaya Terhadap Manajemen Keuangan Pribadi Mahasiswa. Jurnal Pendidikan Akuntansi, 3(3), 1-6. https://ejournal.unesa.ac.id/index.php/jpak/article/view/17112 